\title{
DEATH AND FOREBODING IN ROMEO AND JULIET
}

\section{Francisco SANTIBÁÑNEZ}

Universidad de La Rioja

\section{Introduction}

“Well, we were born to die" (1968: III.4.4), says old Capulet with Tybalt's death in mind, unaware that his words, a common statement after someone has died, will also apply to his daughter by the end of the play, partly because of his immediate decision to ease Juliet's grief with a hasty marriage to Paris. The universal theme of the inevitability of death has been dealt with in different ways by different cultures, approaches ranging from Horace's carpe diem to the Christian belief in death as the anteroom to everlasting life. In Romeo and Juliet, however, death emerges as an ambivalent agent: it strikes the young lovers with all its cruelty (which moves the public to feelings of pity and sorrow) but, at the same time, a certain impression remains that a series of hostile forces make this unfortunate denouement the only possible way to preserve the purity and intensity of their love.

The first two acts of the play are characterized by the predominance of a comic mood; it is there that we can find the atmosphere of celebration of the party at the Capulets' house, Mercutio's bawdy wordplay, the Nurse's garrulousness and, above all, the sincere love between Romeo and Juliet, their marriage being the typical happy ending of Shakespearean romantic comedy. But, in this case, the play must continue, and the fragility of the lovers' happiness soon comes to the surface by means of a sudden movement towards tragedy, marked by the violent deaths of Mercutio and Tybalt and Romeo's subsequent banishment from Verona. To the audience, however, this variation in tone is not unexpected; Shakespeare introduces at the beginning of the play a prologue which, making use of the authoritative comment of an external chorus, leaves out any kind of doubt as to the necessity of a fatal outcome. In addition, the audience's response is also aimed in this direction through the elaborate imagery of death and foreboding that pervades even the apparently most joyful scenes. In this brief essay, therefore, I will try to analyze how a complex system of premonitory signs is put at work to show that the love between Romeo and Juliet is doomed to disaster.

Shakespeare's text is fairly ambiguous with regard to the ultimate cause which drives the lovers to their self-destruction. First, we can find constant references to the influence exerted by fate upon the lives of two characters whose destiny lies in the stars; once the play finishes, it may leave us with a disturbing sense of predestination, of having witnessed the wilful victimization of two innocent beings. Stress is also placed throughout the play on the idea of speed; events succeed each other at a frantic pace, and the lovers' impetuous passion actively partakes of the general hastiness. Furthermore, a hostile social environment, embodied by the feud, proscribes the protagonists' love and throws them into a whirlpool of violence and death from which they will in vain attempt to exclude themselves. 
I will devote a separate section in the essay to the analysis of each of these three dramatic forces (fate, speed and society) in Romeo and Juliet, paying special attention to the way in which the language and imagery of the play may establish some kind of hierarchy among them. A final section will bear upon the tragic status of the play in order to discuss the tendency to regard it as a lyric play in which death serves a central function rather than as an orthodox Shakespearean tragedy (within the line of Hamlet or King Lear).

\section{2. 'A pair of star-crossed lovers'}

Fate is a central thematic element in Romeo and Juliet. In general terms, fate is understood as an external power that determines the lives of the characters independently of human action. The appeal to fate transports modern audiences to a world of superstition in which the utmost importance is attached to the positions and movements of cosmic bodies. Signs are to be found everywhere and it is implied that, in the same way as Greek and Roman generals did not hesitate to postpone a battle until they received favourable responses from the oracles, Romeo and Juliet should not persist in fighting against the inevitability of their adverse destiny.

The Prologue lays down the norm that will be followed throughout the play with relation to the theme of fate; the protagonists are significantly characterized as "a pair of star-crossed lovers" (1968: Prol.6), and further warning notes include 'fatal loins' (5), 'fearful passage' and 'death-marked love' (9). Thus, we can find, for instance, dying Mercutio's triple curse on both families (1968: III.1.91,99-100,106), bloodstained Romeo's complaint that "I am fortune's fool" (1968: III.1.136) or Juliet's bitterly ironic address to 'fickle' Fortune (1968: III.5.60-4). In the middle of his passionate joy, Romeo dares to tempt destiny (1968: II.6.3-8), a dangerous challenge which is made most explicit when the tragic outcome of the play is getting closer: "I defy you, stars!" (1968: V.1.24). Finally, Romeo depicts himself as a slave of tyrannical fate and looks upon suicide as the only way to "shake the yoke of inauspicious stars / From this worldwearied flesh"(1968: V.3.111). Even Friar Laurence, the religious figure of the play, feels compelled to admit the intervention of "A greater power than we can contradict" (1968: V.3.153).

Some critics, however, tend to disregard the role played by fate within the dramatic design of the play. That is the concept of Romeo and Juliet that we can find, for instance, behind Spencer's words (1968: 21): “The verbal emphasis is frequently on fate; but the logic of the play seems to be, rather more than we should like, on chance". This kind of arguments is mainly founded upon the indeterminate distinction between fate and chance. Bradley (1904: 9) defines chance or accident as "any occurrence (not supernatural, of course) which enters the dramatic sequence neither from the agency of a character, nor from the obvious surrounding circumstances". Bradley's own examples of the role played by chance in Shakespearean tragedies include the fact "that Romeo never got the Friar's message about the potion, and that Juliet did not awake from her long sleep a minute sooner". It is undeniable that, at the end of the play, a series of unlucky coincidences, rather than a clear cause-effect relationship, precipitates the death of the lovers. According to Williams (1970: 33), accident "cannot be called Fate, but it is something incalculable and sometimes de- 
structive". It is possible to account for the alleged disagreement between the notion of fateful inevitability and just bad luck, what Friar Laurence refers to as 'lamentable chance' (1968: V.3.146), in terms of young Shakespeare's deficiencies as a playwright, but, at any rate, one's personal experience of the play seems to indicate that, within the dramatic world, there is no obstacle to interpret chance or accident as an instrument for the malignant dictates of fate to materialize.

It is interesting to discriminate between overt and covert foreboding in order to analyze the different ways in which death is anticipated. Overt foreboding is connected with dreams and presages, generally on the part of the lovers, which predict the tragic ending rather explicitly; covert foreboding, however, includes elements (clusters of images, punning, signs, etc.) which become foreshadowing especially in the light of the pervading dramatic irony of the play. The development of covert foreboding patterns is of central importance to emotionally implicate the spectator in the unfortunate fate of the lovers, since they trigger off fairly demanding mechanisms of association.

The first instance of an overt premonitory speech is delivered by Romeo before attending the party at the Capulets' house. Earlier in the scene, the youth warns his friend Mercutio that "'tis not wit to go" (1968: I.4.49) and speaks about a dream. The audience is not allowed to know the content of Romeo's dream, precisely because he is interrupted by Mercutio's long speech about Queen Mab and the insubstantiality of dreams. But the anticipatory nature of Romeo's dream is implied when he expresses his fears that this party will be the beginning of his destruction (observe that the contemplation of suicide is suggested):

\section{For my mind misgives}

Some consequence, yet hanging in the stars,

Shall bitterly begin his fearful date

With this night's revels and expire the term

Of a despisèd life, closed in my breast,

By some vile forfeit of untimely death (1968: I.4.106-11)

Romeo's clear reference to astral influence upon human life ("Some consequence, yet hanging in the stars") takes the audience back to the figure of the "starcrossed lovers" (1968: Prol.6) of the Prologue. What might otherwise be interpreted as a continuation of the kind of insincere language which courtly love would impose upon the rejected lover (Rosaline is expected to attend the masque, and the renewal of her disdainful attitude should "kill" the lover) will acquire a completely new meaning when Romeo meets Juliet and they immediately fall in love. Ironically enough, the prophecy that "this night's revels" will lead to "untimely death", an example of the tension between comedy and tragedy in the play, is to be fulfilled for very different reasons from those Romeo may have in mind.

As regards Juliet, overt premonition of death is postponed until the play has already veered to the tragic side (it is true, however, that some ominous remarks on her part are scattered over previous scenes). After having consummated their marriage, the young lovers are forced to separate because of Romeo's banishment. Juliet 
asks Romeo whether they will meet again; Romeo tries to calm her down by answering in the affirmative, but, in fact, the spectator gets the impression that this is the last time the lovers will speak to each other. Although they are still alive when they meet in Act V, Romeo, believing Juliet to be dead, kills himself; the "sweet discourses" (1968: III.5.53) referred to by Romeo become the disheartening words of each lover before committing suicide. It is within this sinister context that Juliet foresees Romeo's death:

\section{O God, I have an ill-divining soul! \\ Methinks I see thee, now thou art so low, As one dead in the bottom of a tomb. \\ Either my eyesight fails, or thou lookest pale (1968: III.5.54-7)}

This major moment of dark anticipation differs in some respect from Romeo's dream in Act I. In this case, there is no possibility of considering Juliet's words as a manifestation of empty convention. Juliet, who proves a more mature and intelligent character than Romeo all through the play, plainly acknowledges her "ill-divining soul", a superior perceptive degree that enables her to identify Romeo's seeming paleness with death (a terrifying gift here denied to Romeo, who in turn attributes Juliet's paleness to her sorrow). Moreover, the disturbing effect is completed when, just after Romeo and Juliet have parted, the appearance of Lady Capulet to inform her daughter of her imminent wedding to Paris serves to emphasize the existence of a harmful external power that relentlessly pursues the lovers.

As the play advances, a third overt premonitory speech can be found in the soliloquy uttered by Romeo in his Mantuan exile just a few moments before the spectator, whose understanding of the events is superior to the character's, witnesses the heartrending picture of the youth, absolutely oblivious of the plan devised by Friar Laurence, receiving the news of Juliet's alleged death. The anticipation of death is introduced once more in the guise of a dream:

\section{I dreamt my lady came and found me dead- Strange dream that gives a dead man leave to think!- And breathed such life with kisses in my lips That I revived and was an emperor" (1968: V.1.6-9)}

Romeo partly foresees the circumstances of his own death, but the dark presentiment is significantly transformed into a reason for joy: in the unsubstantiality of his dream (Mercutio's Queen Mab speech may come to our mind), Juliet's kisses bring him back to life. Although we are conscious that the play will end calamitously and, therefore, no resurrection is going to take place, we have got the feeling that Romeo and Juliet's genuine love will be kept alive beyond death itself.

A remarkable sense of predestination also governs the occasions when the forces of comedy and tragedy collide on the stage. Thus, for example, in the middle of the atmosphere of joy and celebration in which true love is about to be born between Romeo and Juliet, the figure of Tybalt serves as a reminder of the forecoming turns of 
the plot. The belligerent young Capulet, who considers himself entitled to kill Romeo, promises trouble when he assures that "this intrusion shall, / Now seeming sweet, convert to bitterest gall" (1968: I.5.91-2). The irony underlying these threatening words functions at two different levels: it is Romeo that will kill Tybalt and not the other way round, but it is also true that the pernicious consequences of the event will play a relevant role in the tragic development of the play. Shakespeare emphasizes the effect by choosing the couplet form to put the following anticipatory statement in Romeo's mouth:

This day's black fate on more days doth depend.

This but begins the woe that others must end (1968: III.1.109-10)

As opposed to the grandiloquence of this kind of interventions, what I have called covert foreboding tends to elaborate on the notion of fate with a degree of subtlety. The more or less univocal statements are now replaced mainly by sets of recurrent images as well as by wordplay and, in Mahood's words (1970: 17), "its proleptic second and third meanings". Shakespeare forces language to mean beyond the situational context in which it occurs by making it foreshadow the impending death of the lovers. For example, when Juliet associates Romeo with the figure of the raven, traditionally regarded as a bird of ill omen (1968: III.2.19,76), she unwittingly predicts his death. And Paris is equally unaware that, when he says that "Venus smiles not in a house of tears" (1968: IV.1.8) (that is to say, it might not be appropriate to court Juliet after Tybalt's death), his words also refer to the fatal astral influence that will impel him to become an unnecessary victim of the final rash of violence.

But it is quite probably in the case of Juliet that covert foreboding is more fully developed. Laroque (1993: 205), in a very convincing way, shows how Shakespeare introduces inauspicious calendary associations to define the inherently tragic dimension of Juliet's character from the very moment of her conception: "Thus, in Romeo and Juliet, when the nurse refers to the Lammastide festival to work out Juliet's age, the Elizabethan public would, as it counted back nine months, immediately arrive at the implied festival of Hallowe'en (the night of 31 October-1 November) as the likely date of Juliet's conception. In an age accustomed to intellectual efforts of this type, such calculations would have been virtually automatic and Shakespeare makes use of this principally to indicate, quite early on in the play, that a tragic mechanism with the power to abolish the frontiers between love and death may be at work."

The fact that the calendar tells the truth must be taken for granted; owing to their direct personal involvement in the events, we may have our reasons to distrust some characters when they attribute disaster to the action of fate, but no argument can be provided against the reliability, on a symbolic plane, of an external aspect of the type of calendary associations. Laroque's view is supported by the way in which this piece of information is introduced within the Nurse's speech (1968: I.3.13-49). The Nurse ominously relates Juliet's birth date to Susan, her deceased daughter, a child of the same age who "was too good for me" (21); since it is implied that this will also be the case with Juliet, the audience may rightly guess that the girl will die before her fourteenth birthday. It is also possible to associate Juliet's ill-fated conception with 
her lack of genuine parental affection (we should remember "the fatal loins" of the Prologue and that, in a way, the Nurse is more of a mother for her than Lady Capulet). Another moment in Juliet's life, the time when the Nurse stopped being her mother of breast, is related to a violent, destructive event: an earthquake (an element which adds to the imagery of earth and death discussed just below). And the reference to wormwood may be interpreted as the anticipation both of Juliet's feigned death and, in a more comprehensive way, of the bitterness of her existence. It is surprising to observe the wide variety of premonitory hints that is contained in what paradoxically constitutes one of the best examples of the Nurse's comic garrulousness.

This tragic dimension of Juliet's character is reinforced by her association all through the play with two interrelated sets of images. First, Juliet appears closely related to earth (1968: I.2.14-5;I.5.47;II.1.1-2;II.3.4-8, III.2.59-60 etc.), which anticipates the final scene at the graveyard. Moreover, the ominous connection with earth is supported by the recurrent image of Juliet as Death's bride (1968: I.5.134-5; III.2.135-7; III.5.140; III.5.201-2; V.3.12-3; V.3.92-3). For instance, after having discovered Juliet apparently lifeless, Old Capulet's pompous lament repeatedly employs the image of his daughter's marriage to Death (in this case, from a mainly economic point of view):

O son, the night before thy wedding day

Hath death lain with thy wife. There she lies,

Flower as she was, deflowerèd by him.

Death is my son-in-law. Death is my heir.

My daughter he hath wedded. I will die

And leave him all. Life, living, all is death's (1968: IV.5.35-40)

Later on in the same scene, the situation allows Juliet's erotic association with death to be symbolically enacted on the stage. The preparations for a wedding become the preparations for a funeral, which constitutes another manifestation of the recurrent shift from comedy to tragedy that characterizes the play as a whole:
All things that we ordainèd festival
Turn from their office to black funeral.
Our instruments to melancholy bells;
Our wedding cheer to a sad burial feast;
Our solemn hymns to sullen dirges change;
Our bridal flowers serve for a buried corse;
And all things change them to the contrary (1968: IV.5.84-90)

The image of death as a lover appears again more strongly in the tomb at the end of the play:

Shall I believe

That unsubstantial death is amorous,

And that the lean abhorrèd monster keeps

Thee here in dark to be his paramour? (1968: V.3.102-5) 
As we have seen, it is possible to defend the importance of fate within the play in terms of language and imagery. The fact that the future of the lovers is doomed by the nefarious action of the stars is perfectly consistent with the characteristics of the universe that the playwright proposes to his audience and, therefore, in the same way as it would seem ridiculous to start complaining about the appearance of elves and goblins in fairy tales because we have never happened to meet one in real life, the spectator should take into account the convention of fate in his / her personal reception of the play.

\section{3. 'They stumble that run fast'}

A noticeable characteristic of Romeo and Juliet is the impression that events unfold too quickly before our eyes. The span of the action, which covered several months in Brooke's previous narrative poem about the same story, is reduced here to a few days. As Bradbrook (1964: 109) puts it, "in terms of action, the speed of the plot carries everything along at such a pace that we feel the momentum cannot be checked; at this pace the smallest accident is fatal, the merest rub of circumstance will throw a life away". The idea of speed, a variation on the more general theme of the destructive power of time, becomes a central factor in the tragic development of the play. Thus, all the verbal references to haste or suddenness serve to remind the audience of the inevitability of the final catastrophe:

\section{Although I joy in thee,}

I have no joy of this contract tonight.

It is too rash, too undavised, too sudden;

Too like the lightning, which doth cease to be

Ere one can say 'It lightens'. (1968: II.2.116-20)

Juliet ominously compares their love with the inherently fleeting nature of a flash of lightning. In contrast to Romeo's rash impetuosity, the girl somehow intuits that the intensity of their passion cannot last for very long and, consequently, it is necessarily bound to extinction.

The theme of speed appears beautifully related to mythology in the speech uttered by Juliet as the girl, unaware of the sudden twist of fate that the audience has just witnessed, impatiently looks forward to her wedding night:

\section{Gallop apace, you fiery-footed steeds,}

Towards Phoebus' lodging! Such a waggoner

As Phaëton would whip you to the West

And bring in cloudy night immediately. (1968: III.2.1-4)

The dark notes of this mythological allusion, which aids in inserting the action within a context of superstition, work in the same way as the instances of covert foreboding analyzed in the previous section. Phaëton, according to the myth, unskilledly drove the Sun's chariot too close to the surface of the Earth and was about to set the world on fire; his boldness was punished by Zeus, who killed him with a thunderbolt. This is Bate (1994: 177) on the implications of the motif: "The dramatic 
irony of the allusion is intense. Juliet invokes Phaëthon because she thinks that he could quicken the pace of the sun and thus hurry time on to 'love-performing night'. The irony is that in willing on the night, she is willing on the tragedy, the moment of separation, Romeo's exile, and ultimately the confusion and mistiming which brings the death of both lovers. The audience sees, as the character does not, that to put Phaëthon in charge is to precipitate the catastrophe".

This precipitation of the final disaster is particularly interesting when we approach the theme of speed in terms of character. The lovers are characterized all through the play by the uncontrolled nature of their passion; it seems as if they were always in a hurry. Romeo explicitly acknowledges his eagerness to do things quickly: "I stand on sudden haste" (1968: II.3.89); Friar Laurence warns the lovers that "They stumble that run fast" (1968: II.3.89); both statements bear on the idea of losing one's balance and we fear that, as the play goes on, the inescapable fall will lead the lovers' bodies right to the grave (however, the fact of acting without stopping to think about the possible consequences is not only applicable to the young protagonists, but also, for instance, to Old Capulet's hasty decision to marry Juliet). It is undeniable that the behaviour of the lovers comes out of instinct rather than out of reason, but, since Shakespeare does not judge the young protagonists, we are never really asked to upbraid them for it.

According to Boorman (1987: 141), it is "obvious that the play is driven by the physical passion of the young lovers, and that the dominant theme throughout is of unreason against reason". In my view, however, the only obvious thing is that Boorman, in his attempt to take the play within the domain of human conflict, is tempted by oversimplification. Boorman (1987: 145) virtually reduces the role of fate to that of a merely ironic device that shows the characters' inability to deal with the different situations and, therefore, he denies its importance as a tragic force. Since one may then wonder why Shakespeare takes the trouble to fill the text of the play with covert premonitory hints (e.g. those relative to Juliet's death-marked conception), it seems more appropriate to argue that both aspects (speed and fate) complement each other in order to bring about the destruction of the lovers.

The uncontrolled passion of Romeo and Juliet is also linked to their death by means of the productive imagery of the voyage (1968: I.4.112-3; II.2.82-4; II.4.185-7, etc.). According to Bradbrook (1980: 98), Shakespeare usually relates the sea to "the oceanic feeling, the sense of being lost, or lapsed, into a reciprocal life, a 'universe of two' as a modern poet termed it". Thus, the lovers, cut off from the world that surrounds them, absolutely commit themselves to the dangerous turbulences of an exalted passion. Significantly enough, the sea may also stand for the unpredictability of fate. In the balcony scene, Romeo makes use of the voyage imagery to underline his sincere determination to take any course of action, however extreme it might turn out, in order to preserve his love for Juliet:

I am no pilot; yet, wert thou as far

As that vast shore washed with the farthest sea,

I should adventure for such merchandise. (1968: II.2.82-4) 
Later on in the play, Old Capulet compares Juliet with a bark in the middle of a tempest at sea:

In one little body

Thou counterfeitest a bark, a sea, a wind.

For still thy eyes, which I may call the sea,

Do ebb and flow with tears. The bark thy body is,

Sailing in this salt flood. The winds, thy sighs,

Who, raging with thy tears and they with them,

Without a sudden calm will overset

Thy tempest-tossèd body. (1968: III.5.130-7)

It can be observed how the same elements are disturbingly retaken by Romeo in his final soliloquy when addressing the poison ("thou desperate pilot") with which he is just about to take his life:

Come, bitter conduct, come, unsavoury guide!

Thou desperate pilot, now at once run on

The dashing rocks thy seasick weary bark! (1968: V.3.116-8)

The cluster of images related to the idea of voyage finally moves, in Mahood's words (1970: 18), towards "a rudderless course that must end in shipwreck". Girard (1995: 377) defines the passion of the lovers as "un deseo que no intenta nada a excepción de su propia destrucción apocalíptica". But the idea that lovers voluntarily rush into death for death's sake may erroneously lead us to look upon the play as the actualization of the Liebestod myth, the tragic passion always in search of its own destruction: it should be noted that the solution of suicide is contemplated by the lovers only when some kind of external force (banishment, death, etc.) prevents them from sharing their love together. Shakespeare points up the convergence of love and death in a variety of ways, most effectively by playing on the double meaning of death as 'extinction' and as 'sexual ecstasy' (1968: III.2.21-2). In a way, death is the price Romeo and Juliet have to pay for the immortality of their own love. Let us then finish the section with Prince's (1966: 42) illuminating comment on the manner in which the audience may respond to this complex association: "The difficulty of love as a tragic theme comes partly from our difficulty in feeling that such love as this can be brought ultimately to disaster -except by ceasing to be itself. Perfect love consummated, and then destroyed by death, seems only to be given a further consummation. Those of us who remain, the old people, the responsible, the worldly wise, will put up golden statues and seek to mend our ways: but are we not inescapably in worse case, imprisoned in our lives, than the dead lovers?".

\section{Social death: the perils of isolation}

The main social contribution to the anticipation of death is to be found in the hostilities (their motivations remain unknown to the audience) between the Capulets and the Montagues. The feud is not only the agent that favours the violent character 
of the play but also the external force that isolates the lovers from the world in which they live. Within the social context of Verona, their love is absolutely forbidden, which compels Romeo and Juliet to detach themselves from their respective circles of relatives and friends and attempt to create a universe of their own. But we know that this tremendous enterprise is bound to failure (at least in the sense that the lovers will have to die in order to achieve it).

The conflict between social constraints and individual feelings accounts for the apparent contradiction of Juliet's words after she has been informed of Romeo's identity:

\author{
My only love, sprung from my only hate! \\ Too early seen unknown, and known too late! \\ Prodigious birth of love it is to me \\ That I must love a loathèd enemy. (1968: I.5.138-41)
}

We immediately understand which words are uttered from a social viewpoint ('hate', 'prodigious', 'a loathèd enemy') and which others come from Juliet's heart ('love', 'birth of love', 'love'). The love between Romeo and Juliet is in sharp contrast with the hate between their families. At the end of the play, the death of the lovers will have a direct effect on the corrupted social life of Verona. The absurdity of the feud is finally recognized by means of the reconciliation between the two families, a movement which involves the restoration of harmony within the so-called chain of being.

Social death can also be interpreted, as far as Juliet's character is concerned, from the perspective of feminist criticism. This kind of approach is supported by the fact that, rather exceptionally, the tragic dimension of the feminine figure is further developed than that of Romeo. Kahn, quoted by Levin (1988: 126), argues that "the primary tragic force" in the play is "the feud as an extreme and peculiar expression of patriarchal society, which Shakespeare shows to be tragically self-destructive". An interesting example of the destructive power of patriarchy (the system that favours a world organized by men to their own advantage) is the brutal treatment received by Juliet from her parents when she refuses to marry Paris, that is to say, when she rebels against the socially accepted values. Peck and Coyle (1995: 199) point out that Juliet "seems to be destined to die not for reasons of fate or character but because of the culture that shapes her life and death". This perspective may provide some illuminating insights, but, unfortunately, it often tends to oversimplify the complexities of the dramatic universe of the play.

Finally, language constitutes another example of the pressure that social forces are able to exert on the individual, since it makes personal identity subservient to a public code; language is a socially coded convention that must satisfy social requirements. It cannot be used to convey truth values and, therefore, it fails to fit the context of the sincere love between Romeo and Juliet. Lucking (1995) explains the destruction of the lovers in terms of their impossibility to escape from a world of names. In the cosmos proposed by the play, the conflict is embodied, for instance, by a number of letters and messages which never reach their intended destination. 


\section{Is Romeo and Juliet a tragedy?}

Once the sources of death in Romeo and Juliet have been examined, I will deal briefly with the place taken up by the play with regard to Shakespeare's tragic production and to the notion of tragedy in general. Critics do not agree whether this is a real tragedy or merely a play in which some tragic elements have been introduced. In fact, the first half of the play is dominated by comedy and the central thematic aspec is the love between Romeo and Juliet rather than their death (although it is palpable that both realities come very close to each other in the universe of the lovers). Nevertheless, the comic tone is never really at ease inside the dramatic design of the play, especially because of the ominously revealing nature of the Prologue.

First, it is necessary to determine whether we intend to classify the play as a tragedy of character or as a tragedy of fate. Shakespeare's great tragedies (Hamlet, Macbeth, Othello, King Lear) are more or less prototypical instances of what a tragedy of character must be like. Those plays introduce the figure of a hero that is somehow flawed and, therefore, at least partly responsible for his own death. However, as far as Romeo and Juliet are concerned, it is possible to regard their reckless impetuosity as a weakness, but not as a proper tragic fault that may trigger off the final catastrophe. In this respect, we could say that the play differs from the general Shakespearean concept of tragedy; Morris (1985: 14-5) argues that "Shakespeare did not write the play to be dissected by scholars 'as a pattern of the idea of tragedy'. He wrote it to waken in the audience in the theatre tragic feelings of sacrifice, waste and desolation". Whether we accept the play as a tragedy or not will probably depend upon our personal actualization of those intentions.

As already pointed out, the play responds more accurately to the characteristics of the tragedy of fate. The lovers are sentenced to death by the action of outside forces beyond their control. But this does not necessarily imply that the play has nothing to tell us about the intricacies of human condition. At least, that is not the impression one gets when observing the extent to which Romeo and Juliet meet the requirements derived from Leech's (1989: 46) illuminating definition of the tragic hero as "a man [or a woman] who reminds us strongly of our own humanity, who can be accepted as standing for us". Thus, it is possible to approach the play as an ambivalent analysis of the restraints operated on free will and personal responsibility; or we can say that Romeo and Juliet is a tragedy of human passion that partakes of Bradley's idea (1904: 28) that tragedy is always "a painful mystery".

\section{Conclusion}

In this essay, I have tried to account for the treatment of the theme of death in what is nowadays popularly considered the quintessence of romantic love, Shakespeare's Romeo and Juliet. Stress has been placed all through the essay upon the structural importance of dramatic irony and foreboding, which transform the abundant anticipatory apparatus of the play (expressed by dreams, presages, recurrent images, wordplay, etc.) into a major element of cohesion that serves to integrate comedy and tragedy, love and death. 
Furthermore, I have used different arguments in order to justify the idea that fate functions as a primary force in the particular universe created by the play. Complementary forces, analyzed under the general headings of speed and society, may be interpreted as instruments for the stars to exert their fateful influence. But it would perhaps be more accurate to speak about the interaction of a variety of forces which concur to bring about the tragic end of the lovers.

\section{WORKS CITED}

BRADBROOK, M.C. 1964 (1951), Shakespeare and Elizabethan Poetry, Harmondsworth (Penguin).

BRADBROOK, M.C. 1980 (1978), Shakespeare. The Poet in his World, London (Methuen).

BRADLEY, A.C. 1904, Shakespearean Tragedy, London (Macmillan).

BRENNAN, Anthony 1988 (1986), Shakespeare's Dramatic Structures, London \& New York (Routledge).

GIBBONS, Brian 1996 (1980), “Introduction”, in SHAKESPEARE, William 1996 (1597), Romeo and Juliet London-New York (Routledge), pp.1-77.

GIRARD, René 1995 (1990), Shakespeare. Los fuegos de la envidia, trans. by Joaquín JORDA, Barcelona (Anagrama).

LAROQUE, François 1993 (1988), Shakespeare's Festive World, trans. by Janet LLOYD, Cambridge (Cambridge University Press).

LEECH, Clifford 1989 (1969), Tragedy, London-New York (Routledge).

LUCKING, David 1995, “That Which We Call a Name: The Balcony Scene in Romeo and Juliet", English 44, (n.178), 1-16 [Glasgow, The English Association].

MAHOOD, M.M. 1970 (1957), “Wordplay in Romeo and Juliet”, in Laurence LERNER (ed.), 1970 (1963), Shakespeare's Tragedies. An Anthology of Modern Criticism, Harmondsworth (Penguin), pp.17-32.

MORRIS, Helen 1985, Romeo and Juliet, London (Macmillan).

PECK, John and COYLE, Martin 1995 (1985), How to Study a Shakespeare Play, London (Macmillan).

PRINCE, F.T. 1966, “A Note on Romeo and Juliet”, in Kenneth MUIR, 1966 (1961), Shakespeare: The Great Tragedies, London (Long-mans, Green \& Co), pp.39-43.

ROSTON, Murray 1982, Sixteenth-Century English Literature, London (Macmillan).

SANDERS, Andrew 1994, The Short Oxford History of English Literature, Oxford (Oxford University Press).

SHAKESPEARE, William 1968 (1597), Romeo and Juliet, Harmondsworth (Penguin).

SPENCER, T.J.B. 1968 (1967), “Introduction”, in William SHAKESPEARE, 1968 (1597), Romeo and Juliet, Harmondsworth (Penguin) pp.7-44. 
WILLIAMS, Charles 1970 (1932), "Romeo and Juliet in the Cycle of Shakespeare", in Laurence LERNER (ed.) 1970 (1963), Shakespeare's Tragedies: An Anthology of Modern Criticism, Harmondsworth (Penguin) pp.33-35. 